Sari Pediatri, Vol. 4, No. 3, Desember 2002: 129 - 134

\title{
Imunogenitas dan Keamanan Vaksin DPT Setelah Imunisasi Dasar
}

\author{
Eddy Fadlyana, Suganda Tanuwidjaja, Kusnandi Rusmil, Meita Dhamayanti, Lina H Soemara, \\ $R$ Dharmayanti
}

\begin{abstract}
Imunisasi difteria, pertusis dan tetanus (DPT) telah lama masuk ke dalam program imunisasi nasional di Indonesia dan telah terbukti menurunkan angka kejadian maupun kematian yang disebabkan penyakit difteria, pertusis dan tetanus. Tujuan penelitian ini untuk melakukan evaluasi status kekebalan dan faktor keamanan terhadap penyakit difteria dan tetanus pada bayi yang mendapat imunisasi dasar DPT. Seratus enam puluh subjek bayi sehat yang dipilih secara random, dilakukan imunisasi secara intramuskular dengan dosis $0,5 \mathrm{ml}$ sebanyak 3 kali pada umur 2, 3 dan 4 bulan, menggunakan vaksin DPT buatan PT. Bio-Farma Bandung. Penentuan titer antibodi difteria dan tetanus dilakukan sebelum dilakukan imunisasi dan 1 bulan setelah imunisasi ke-1, 2 dan 3, menggunakan metode ELISA. Apabila hasilnya $<0,01 \mathrm{IU} / \mathrm{ml}$ disebut kelompok rentan dan bila $>0,1 \mathrm{IU} / \mathrm{ml}$ disebut mempunyai kekebalan lengkap. Kejadian reaksi lokal (nyeri, kemerahan, bengkak, penebalan) dan sistemik (demam, iritabilitas) pasca imunisasi dicatat dalam buku catatan harian ibu. Hasil penelitian menunjukkan sebelum dilakukan imunisasi $57 \%$ subjek sudah tidak mempunyai perlindungan terhadap difteri dan $6 \%$ sudah tidak mempunyai perlindungan terhadap tetanus. Terhadap difteria, rata-rata geometrik titer (GMT) sebelum dan setelah mendapat imunisasi ke-1, 2 dan 3, memberikan hasil berturut-turut 0,008; 0,005; 0,038; dan 0,217 IU/ml; sedang jumlah subjek yang mempunyai titer $\geq 0,01 \mathrm{IU} / \mathrm{ml}$ berturut-turut adalah $44,28,44$ dan $80 \%$. Terhadap tetanus, rata-rata geometrik titer (GMT) sebelum dan setelah mendapat imunisasi ke-1, 2 dan 3, memberikan hasil berturut-turut: 0,$420 ; 0,273 ; 0,213$; dan $0,758 \mathrm{IU} / \mathrm{ml}$; jumlah subjek yang mempunyai titer $\geq 0,01 \mathrm{IU} / \mathrm{ml}$ berturtut-turut adalah 94; 91; 100 dan 100\%. Selama periode penelitian tidak ditemukan adanya reaksi vaksin berat. Reaksi lokal (nyeri, kemerahan, bengkak dan penebalan) dan reaksi sistemik (iritabilitas dan panas) sebagian besar dengan derajat ringan yang selanjutnya menghilang tanpa gejala sisa. Walaupun imunisasi DPT memberikan hasil kekebalan yang tinggi dan aman diberikan, namun pada kelompok yang masih rentan perlu mendapat perhatian.
\end{abstract}

Kata kunci: imunisasi DPT, respons imun, keamanan vaksin.

Dr. Lina Herliana Soemara, Msc.

Divisi Surveilans \& Epidemiologi P.T Bio Farma

Jalan Pasteur no. 28, Bandung.

Tel. 022-2033755/2037430, Fax. 2037430/2041306.

e-mail: lina.soemara@biofarma.co.id

Alamat korespondensi:

Dr. Eddy Fadlyana, Sp.A

Staf Subbagian TK-Ped.Sos, Bagian Ilmu Kesehatan Anak Fk. Universitas

Padjajaran, Bandung.

Telepon: 022-2034426, Fax.: 022-2035957.
$\mathcal{M}$ anusia dapat terinfeksi oleh kuman difteria, pertusis, dan tetanus; namun pada mereka yang mempunyai kekebalan walaupun terinfeksi namun gejala klinis lebih ringan dengan angka kematian yang lebih rendah dibandingkan mereka yang tidak mendapat imunisasi. ${ }^{1}$ Upaya imunisasi difteria, pertusis, dan tetanus (DPT) secara masal dianggap merupakan cara yang paling tepat untuk meningkatkan status kekebalan seseorang 
terhadap penyakit yang berbahaya ini. ${ }^{2}$ Program imunisasi DPT yang dilaksanakan di negara maju telah berhasil menurunkan angka kejadian dan kematian akibat penyakit difteria, pertusis, dan tetanus. Misalnya di Amerika Serikat pada beberapa tahun terakhir ini hanya ditemukan kurang dari 5 kasus difteria, demikian juga untuk penyakit pertusis, dan tetanus sudah sangat jarang ditemukan. ${ }^{3}$

Di Indonesia program imunisasi DPT sudah menunjukkan keberhasilan walaupun tidak sebaik yang dicapai oleh negara maju. Pada tahun 1974 WHO mencanangkan pengembangan program imunisasi (PPI), dan sejak tahun 1979 PPI telah dilaksanakan secara nasional di Indonesia. ${ }^{4}$ Berdasarkan laporan Depkes RI, sejak tahun 1990 ratarata cakupan imunisasi dasar DPT sudah mencapai $\pm 90 \%$. Keberhasilan pencapaian cakupan imunisasi DPT ini sejalan dengan penurunan kejadian kasus maupun kematian. Pada tahun 1990 tercatat 1.157 kasus difteria, 429 pertusis dan 5072 tetanus; dengan kematian 81 kasus akibat difteria, 774 kasus akibat tetanus dan tidak kematian akibat pertusis. Sedangkan pada tahun 1995 didapat 258 kasus difteria, 124 pertusis, dan 2.425 tetanus; dengan jumlah kematian 17 kasus akibat difteria, 3 pertusis dan 338 kasus tetanus. ${ }^{4,5}$ Dengan menurunnya angka kesakitan dan kematian anak pada umumnya, maka kualitas hidup bangsa diharapkan akan meningkat pula. Pemberian imunisasi pada bayi dan anak tidak hanya memberikan pencegahan terhadap anak tersebut tetapi akan memberikan dampak yang jauh lebih luas karena akan mencegah terjadinya penularan yang luas dengan adanya peningkatan tingkat imunitas secara umum di masyarakat. ${ }^{6}$ Setelah program imunisasi DPT cukup lama dilaksanakan di Indonesia, saat ini diperlukan data mutakhir mengenai respons imun yang ditimbulkan dan faktor keamanan. Data ini sangat diperlukan untuk pengembangan vaksin DPT selanjutnya.

\section{Subjek dan Metoda}

\section{Subjek Penelitian}

Penelitian ini dilakukan di Puskesmas Garuda dan Padasuka kota Bandung, pada bulan Juli - November 2001. Penelitian dilakukan dengan cara one group prepost test design. Subjek adalah bayi sehat berumur 2 bulan (antara 7-11 minggu) yang lahir cukup bulan, imunoglobulin, prednison $>2$ minggu, produk darah, bayi sudah mendapat imunisasi DPT, selama pengamatan terjadi reaksi ikutan berat, baik reaksi lokal maupun sistemik. Pemeriksaan dokter dilakukan setiap kali sebelum vaksinasi, terhadap semua subjek penelitian untuk menentukan tidak ada indikasi kontra vaksinasi.

\section{Vaksin}

Vaksin DPT yang digunakan adalah buatan PT. Bio Farma Bandung, setiap dosis $0,5 \mathrm{ml}$ mengandung 20 Lf toksoida difteria yang dimurnikan; 7,5 Lf tetanus toksoid yang dimurnikan; 12 milyar kuman $B$. pertussis; $1,5 \mathrm{mg}$ aluminium fosfat dan $0,05 \mathrm{mg}$ mertiolat. ${ }^{7}$

\section{Imunisasi}

Imunisasi dilakukan oleh dokter di Klinik Puskesmas sesuai dengan jadwal imunisasi dasar yang dianjurkan Departemen Kesehatan RI yaitu pada umur 2, 3, dan 4 bulan. Selama melakukan imunisasi, vaksin ditempatkan dalam cool box dengan suhu selalu dipertahankan antara $2-8^{\circ} \mathrm{C}$. Vaksin diberikan secara intramuskular pada tungkai atas kaki kanan, menggunakan disposible syringe dengan jarum no $28(16 \mathrm{~mm})$.

\section{Analisis imunogenitas}

Pengambilan darah dilakukan 4 kali yaitu sebelum dilakukan imunisasi dan 1 bulan setelah imunisasi yang ke-1, 2 dan 3 (untuk pengambilan darah setelah imunisasi ke-2 dan ke-3 dipilih secara random terhadap $50 \%$ subjek). Sampel darah diambil dari vena kubiti sebanyak 2,5 ml menggunakan syringe dan wing needle. Serum dipisahkan dengan cara sentrifugasi, dimasukkan dalam vial, kemudian disimpan dalam suhu beku sampai saat dilakukan pemeriksaan.

Semua pemeriksaan serologis dilakukan di laboratorium surveilans dan epidemiologi PT. BioFarma Bandung. Titer anti difteria dan tetanus diperiksa dengan metode ELISA, dengan satuan international unit per $\mathrm{ml}(\mathrm{IU} / \mathrm{ml})$. Bila hasil titer difteria atau tetanus $<0,01 \mathrm{IU} / \mathrm{ml}$ dikelompokkan sebagai rentan; $\geq 0,01-<0,1 \mathrm{IU} / \mathrm{ml}$ mempunyai antibodi protektif minimal; sedangkan bila $\geq 0,1 \mathrm{IU} /$ $\mathrm{ml}$ mempunyai perlindungan lengkap. ${ }^{8}$ 


\section{Analisis keamanan}

Setiap kali akan mendapat imunisasi, dilakukan pemeriksaan fisis, dan setelah mendapat imunisasi dilakukan pengamatan langsung oleh dokter selama 30 menit. Orang tua dilibatkan untuk melakukan pengamatan kejadian ikutan pasca imunisasi, terutama pada 3 hari pertama dan melakukan pengukuran suhu aksila 3 kali sehari. Semua kejadian/gejala reaksi dicatat dalam buku catatan harian ibu. Pada hari ke-3 setelah imunisasi dilakukan kunjungan rumah oleh petugas kesehatan. Gejala lokal yang diamati adalah bengkak, kemerahan, dan nyeri pada penekanan. Sedangkan gejala umum yang diamati adalah suhu badan, iritabilitas (menangis lebih lama dari biasanya), dan kejang. Juga diamati kejadian lokal dan sistemik di antara 3 hari setelah suntikan sampai kunjungan berikutnya.

\section{Analisis statistik}

Respons imun sebelum dan sesudah imunisasi dibandingkan dengan uji Wilcoxon untuk data berpasangan. Insidens kejadian lokal dan sistemik pada tiap vaksinasi diuji dengan Mc Nemar. Seluruh perhitungan statistik dikerjakan dengan piranti lunak
SPSS versi 10.0 for Windows, tahun 1999, SPSS Inc, Chicago-Illinois, Amerika Serikat.

\section{Hasil Penelitian}

Pada awal penelitian dijumpai 160 bayi yang memenuhi kriteria inklusi (58\% laki-laki dan 42\% perempuan). Seratus lima puluh lima subjek mengikuti penelitian sampai selesai (97\%), 5 subjek tidak mengikuti penelitian sampai selesai dengan alasan pindah rumah ke luar kota. Umur rata-rata pada saat kunjungan pertama adalah $65 \pm 9$ hari. Semua subjek dengan keadaan fisik sehat dan mempunyai status gizi baik.

\section{Serologi}

Respons serologi terhadap difteria dan tetanus dapat dilihat pada Tabel 1. Antibodi terhadap difteria sebelum dilakukan imunisasi terdapat pada $44 \%$ subjek dengan titer rata-rata (geometric mean titer $=$ GMT) $0,008 \mathrm{IU} / \mathrm{ml}$, setelah imunisasi ke-1 terjadi penurunan secara bermakna ( $\mathrm{p}<0,001)$, dan baru meningkat secara bermakna setelah imunisasi ke-2 ( $\mathrm{p}=0,004)$. Sembilan puluh empat persen subjek mempunyai zat anti

Tabel 1. Imunogenitas terhadap anti difteri dan anti tetanus sebelum dan sesudah imunisasi DPT

\begin{tabular}{|c|c|c|c|c|}
\hline Titer serologi & $\begin{array}{l}\text { Sebelum } \\
\text { imunisasi } \\
(\mathrm{n}=160) \\
\mathrm{I}\end{array}$ & $\begin{array}{c}\text { Setelah } \\
\text { imunisasi } 1 \\
(\mathrm{n}=80) \\
\text { II }\end{array}$ & $\begin{array}{c}\text { Setelah } \\
\text { imunisasi } 2 \\
(\mathrm{n}=80) \\
\text { III }\end{array}$ & $\begin{array}{c}\text { Setelah } \\
\text { imunisasi } 3 \\
(\mathrm{n}=154) \\
\text { IV }\end{array}$ \\
\hline \multicolumn{5}{|l|}{ Anti difteria* } \\
\hline Geometric mean titer $(\mathrm{IU} / \mathrm{ml})$ & 0,008 & 0,005 & 0,038 & 0,217 \\
\hline Proporsi $(\mathrm{n} \%) \geq 0,01-0,1$ & $34(21,4)$ & $0(0,0)$ & $25(32,0)$ & $1(0,6)$ \\
\hline$>0,1$ & $35(22,1)$ & $22(27,5)$ & $9(11,5)$ & $123(79,4)$ \\
\hline Simpang baku & 0,021 & 0,015 & 0,077 & 0,348 \\
\hline Rentang & $0-0,215$ & $0-0,084$ & $0-0,390$ & $0-2,650$ \\
\hline \multicolumn{5}{|l|}{ Anti tetanus ${ }^{* *}$} \\
\hline Geometric mean titier (IU/ml) & 0,420 & 0,273 & 0,213 & 0,758 \\
\hline Proporsi $(\mathrm{n} \%) \geq 0,01-0,1$ & $1(0,6)$ & $0(0,0)$ & $24(30,0)$ & $0(0,0)$ \\
\hline$>0,1$ & $149(93,7)$ & $72(91,1)$ & $56(70,0)$ & $154(100,0)$ \\
\hline Simpang baku & 0,407 & 0,297 & 0,246 & 0,886 \\
\hline Rentang & $0-2,358$ & $0-1,291$ & $0,028-1,207$ & $0,032-4,787$ \\
\hline
\end{tabular}

* Perbandingan titer anti difteria

I vs II: $p<0,001$, I vs III: $p=0,004$, I vs IV: $p<0,001$, II vs IV: $p<0,001$, III vs IV: $p<0,001$

** Perbandingan titer anti tetanus

I vs II: $\mathrm{p}<0,001$, I vs III: $\mathrm{p}<0,001$, I vs IV: $\mathrm{p}<0,001$, II vs IV: $\mathrm{p}<0,001$, III vs IV: $\mathrm{p}<0,001$ 
terhadap tetanus sebelum dilakukan imunisasi dengan titer rata-rata $(\mathrm{GMT}) 0,420 \mathrm{IU} / \mathrm{ml}$. Terjadi penurunan secara bermakna sampai imunisasi yang ke $2(\mathrm{p}<0,001$ dan $\mathrm{p}<0,001)$ dan meningkat secara bermakna setelah imunisasi ke-3 ( $\mathrm{p}<0,001)$. Setelah mendapat 3 kali imunisasi DPT tidak semua subjek mempunyai kekebalan terhadap difteria $(79,4 \%)$.

\section{Kejadian Ikutan Pasca Imunisasi}

Dalam 30 menit pertama setelah imunisasi tidak didapatkan reaksi ikutan yang dilaporkan. Reaksi lokal dan sistemik yang terjadi selama 3 hari pertama setelah imunisasi dapat dilihat pada Tabel 2. Reaksi lokal berupa nyeri terdapat pada $65 \%$ subjek setelah imunisasi ke-1 dan berkurang setelah imunisasi ke-2 dan ke-3, penurunan ini secara statistik tidak bermakna $(\mathrm{p}=0,012)$. Namun, untuk keluhan lokal lainnya, yaitu kemerahan, bengkak dan penebalan terjadi penurunan secara bermakna setelah imunisasi yang ke- 2 dan ke3. Reaksi sistemik demam setelah imunisasi pertama terjadi pada 63\% subjek dan berkurang setelah imunisas ke-2 dan ke-3, namun secara statisitik tidak bermakna $(\mathrm{p}=0,021)$. Untuk keluhan sistemik lainnya berupa iritabilitas terjadi penurunan dari 58\% setelah imunisasi ke-1, menjadi 28\% setelah imunisasi ke-3, dan perbedaan ini secara statistik bermakna $(\mathrm{p}<0,001)$. Selama penelitian tidak ditemukan reaksi ikutan berat, sebagian besar kejadian lokal dan sistimik yang didapat dikategorikan mempunyai derajat ringan yang dalam pemantauan selanjutnya hilang tanpa meninggalkan gejala sisa.

\section{Diskusi}

Pada penelitian ini, 44\% diantara 155 bayi berumur 2 bulan yang belum mendapat imunisasi DPT masih memiliki kekebalan terhadap difteria dengan kadar rata-rata $0,008 \mathrm{IU} / \mathrm{ml}$, sedangkan sisanya $56 \%$ merupakan kelompok yang rentan terhadap difteria. Penelitian yang dilakukan oleh Prijanto,dkk. ${ }^{9}$ menunjukkan hasil sebesar 99\% yang masih memiliki kekebalan terhadap difteria, dengan titier rata-rata 0,084 HAU/ml. Penelitian Berbaum,dkk. di Amerika Serikat menunjukkan $100 \%$ subjek masih mempunyai kadar proteksi terhadap difteria, ${ }^{10}$ dan penelitian Watemberg,dkk. menunjukkan kadar rata-rata sebesar 0,03 IU/ml. ${ }^{11}$ Hasil penelitian epidemiologi di Swedia menunjukkan terdapat hubungan erat antara tingginya titer antibodi dengan perlindungan klinis. Pada semua pasien yang meninggal atau menderita komplikasi neurologik akibat difteria mempunyai titier antibodi $<0,01 \mathrm{IU} / \mathrm{ml}$; sedangkan pada karier yang tidak menunjukkan gejala sakit mempunyai titer antibodi yang tinggi $>0,16 \mathrm{IU} / \mathrm{ml} .{ }^{12}$ Di Indonesia, tingginya hasil kekebalan bawaan dari ibu terhadap difteria diduga akibat infeksi alami, sedangkan di Amerika Serikat dan negara maju lainnya mungkin akibat tingginya cakupan imunisasi yang mengandung antigen difteria.

Persentase bayi yang kebal terhadap difteria setelah imunisasi ke-1 dan ke-2 menunjukkan penurunan, baru kemudian meningkat setelah imunisasi yang ke3 , dengan kadar rata-rata 0,217 IU/ml. Hal ini menunjukkan bahwa pengaruh zat antibodi bawaan

Tabel 2. Gejala lokal dan sistemik pada tiap vaksinasi

\begin{tabular}{|c|c|c|c|c|c|c|c|}
\hline \multirow[t]{2}{*}{$\begin{array}{l}\text { Kejadian ikutan } \\
\text { pasca imunisasi }\end{array}$} & \multicolumn{2}{|c|}{$\begin{array}{c}\text { Setelah } \\
\text { imunisasi ke-1 } \\
(\mathrm{n}=158)\end{array}$} & \multicolumn{2}{|c|}{$\begin{array}{c}\text { Setelah } \\
\text { imunisasi ke-2 } \\
(\mathrm{n}=156)\end{array}$} & \multicolumn{2}{|c|}{$\begin{array}{l}\text { Setelah } \\
\text { imunisasi ke-3 } \\
(\mathrm{n}=156)\end{array}$} & \multirow{2}{*}{$\begin{array}{c}\text { Perbandingan } \\
\text { antara imunisasi } \\
\text { ke-1 dan } 3 \\
p\end{array}$} \\
\hline & $\mathrm{n}$ & $\%$ & $\mathrm{n}$ & $\%$ & $\mathrm{n}$ & $\%$ & \\
\hline \multicolumn{8}{|l|}{ - Lokal } \\
\hline Nyeri & 103 & 65,2 & 89 & 57,1 & 82 & 52,6 & 0,012 \\
\hline Kemerahan & 80 & 50,6 & 54 & 34,6 & 45 & 28,8 & $<0,001$ \\
\hline Bengkak & 46 & 29,1 & 33 & 21,2 & 25 & 16,0 & 0,005 \\
\hline Pengerasan & 32 & 20,3 & 12 & 7,7 & 11 & 7,0 & $<0,001$ \\
\hline \multicolumn{8}{|l|}{-Sistemik } \\
\hline \multicolumn{8}{|l|}{ Demam $\left({ }^{\circ} \mathrm{C}\right)$} \\
\hline$>37,5-38,9$ & 86 & 53,7 & 72 & 46,2 & 66 & 42,3 & 0,021 \\
\hline$>38,9-39,5$ & 3 & 1,9 & 2 & 6,0 & 4 & 9,3 & \\
\hline Iritabilitas & 92 & 58,2 & 64 & 41,0 & 43 & 27,6 & $<0,001$ \\
\hline
\end{tabular}


dari ibu masih tampak sampai pemberian imunisasi ke-2. Hasil ini menyerupai hasil yang didapat oleh Prijanto,dkk. yang menunjukkan peningkatan baru terjadi setelah imunisasi DPT ke- $2,{ }^{9}$ demikian juga Watemberg, dkk. yang menunjukkan peningkatan setelah imunisasi ke-2, dengan kadar rata-rata 0,43 IU/ $\mathrm{ml} .{ }^{11}$ Hasil ini berbeda dengan penelitian Setiawan di Jakarta yang melaporkan bahwa antara 71-94\% bayi saat imunisasi pertama belum memiliki kadar antibodi protektif terhadap difteria, dan setelah mendapat imunisasi DPT sebanyak 3 kali didapatkan 68-81\% bayi telah memiliki kadar antibodi protektif terhadap difteria dengan rata-rata $0,0378 \mathrm{IU} / \mathrm{ml} .{ }^{13}$ Penelitian Bernbaum, dkk. ${ }^{10}$ di Amerika Serikat menunjukkan sebelum dan sesudah dilakukan 3 dosis imunisasi DPT, $100 \%$ subjek mempunyai kadar proteksi terhadap difteria. ${ }^{10}$ Respons imun yang terbentuk berhubungan dengan umur saat imunisasi. Pada bulan-bulan pertama kehidupan kekebalan bawaan dari ibu masih tinggi, hal ini mempunyai efek menetralkan. ${ }^{14}$ Demikian juga hasil penelitian di Amerika Serikat memberikan kesimpulan yang sama, antibodi maternal yang $>0,1$ $\mathrm{IU} / \mathrm{ml}$ akan mempengaruhi respons imun yang terbentuk. ${ }^{15}$ Pada imunisasi dasar DPT dengan jadwal 2, 4 dan 6 bulan, titer antibodi meningkat sejak dosis ke-2 dan meningkat secara tajam setelah mendapat 3 dosis. Dari semua subjek yang diamati $94-100 \%$ mempunyai tingkat kekebalan $>0,01 \mathrm{IU} / \mathrm{ml} .{ }^{16}$

Pada penelitian ini persentase anak umur 2 bulan yang mempunyai kekebalan terhadap tetanus sebelum dilakukan imunisasi adalah $94 \%$ dengan nilai rata-rata titer anti tetanus sebesar $0,420 \mathrm{IU} / \mathrm{ml}$. Penelitian Prijanto, dkk 9 . memberikan hasil 99\% sedangkan penelitian Watenberg, dkk. dengan rata-rata titer anti tetanus sebesar $0,23 \mathrm{IU} / \mathrm{ml} .{ }^{11}$ Seorang bayi mendapat kekebalan (IgG) dari ibu sewaktu dia berada dalam kandungan melalui plasenta. Hal ini hanya terjadi pada bayi dari ibu yang mempunyai kekebalan terhadap tetanus dengan cara imunisasi, sedangkan seseorang yang baru sembuh dari sakit tetanus tidak akan membentuk kekebalan terhadap serangan yang akan datang. ${ }^{17}$

Persentase bayi yang kebal terhadap tetanus setelah imunisasi ke-1 dan ke-2 menunjukkan penurunan, baru kemudian meningkat menjadi $100 \%$ setelah imunisasi ke-3 dengan kadar rata-rata $0,758 \mathrm{IU} / \mathrm{ml}$. Penelitian Prijanto,dkk. juga menunjukkan $100 \%$ bayi dengan titer proteksi terhadap tetanus sesudah mendapat 3 dosis vaksin DPT. ${ }^{9}$ Penelitian Watenburg,dkk. menunjukkan peningkatan setelah imunisasi ke-2, dengan nilai ratarata sebesar 3,45 IU/ml setelah imunisasi yang ke-3. ${ }^{11}$ Kekebalan bawaan dari ibu akan menekan sementara repons imun setelah imunisasi DPT. Suatu penelitian memperlihatkan bahwa pengaruh kekebalan bawaan dari ibu akan berpengaruh sampai dosis ke- 2 imunisasi dasar DPT yang diberikan pada umur 2 sampai 6 bulan dan 3 sampai 7 bulan. ${ }^{17}$ Pengaruh negatif kekebalan bawaan ini terutama pada anak yang mempunyai titer antibodi $>0,1 \mathrm{IU} / \mathrm{ml}$. Data dari Thailand pada bayi yang mendapat imunisasi pada umur 3, 4 dan 6 bulan memperlihatkan efek penekananan dari kekebalan pasif ini sampai dosis ke-1. ${ }^{17}$ Hasil penelitian di negara maju (Amerika Serikat), sebagian besar wanita usia subur mempunyai kekebalan terhadap tetanus, pengaruh kekebalan yang diberikan pada anaknya akan berpengaruh sampai dosis ke-1 imunisasi dasar DPT. ${ }^{17}$ Setelah mendapat imunisasi dasar sebanyak 3 kali, maka persentase subjek yang mempunyai nilai proteksi > $0,01 \mathrm{IU} / \mathrm{ml}$ untuk difteria dan tetanus masing-masing sebesar 80 dan $100 \%$, sehingga masih terdapat $20 \%$ yang mempunyai nilai di bawah nilai proteksi dan disebut sebagai kelompok yang rentan terhadap infeksi difteria. ${ }^{18}$

Selama periode penelitian tidak didapatkan reaksi berat yang dilaporkan. Reaksi lokal berupa nyeri, kemerahan, bengkak dan pengerasan yang terjadi setelah imunisasi ditemukan pada lebih kurang $50 \%$ subjek, sebagian besar dengan derajat ringan, selama 3 hari pengamatan menunjukkan perbaikan, dan selanjutnya menghilang tanpa gejala sisa. Demikian juga untuk reaksi sistemik berupa demam, walaupun didapat pada lebih dari $40 \%$ kasus setiap kali mendapat imunisasi, akan tetapi yang mempunyai panas badan antara $38,9-39,5^{\circ} \mathrm{C}$ kurang dari $10 \%$, dan tidak ada yang menderita kejang akibat demam, serta tidak ada yang mempunyai suhu badan $>39,5^{\circ} \mathrm{C}$. Hasil penelitian ini menunjukkan hasil yang tidak jauh berbeda dengan hasil yang dilakukan Cody,dkk. ${ }^{19}$ Berhaum, dkk., ${ }^{10}$ dan Watenberg, dkk. ${ }^{11}$ yang sama-sama menggunakan vaksin DPT (whole cell) sebagai bahan penelitian. Namun penelitian Nolan, dkk. yang memberikan parasetamol secara rutin sebelum dilakukan imunisasi, menunjukkan hanya 30\% subjek yang mengalami demam setiap kali dilakukan imunisasi. ${ }^{20}$ Kejadian iritabilitas berkurang secara bermakna dari 58\% subjek setelah imunisasi ke-1 menjadi $28 \%$ setelah imunisasi ke-3. Hasil ini berbeda dengan penelitian Bernbaum, dkk. yang mendapatkan subjek yang mengalami iritabilitas 
setelah imunisasi DPT ke-1 sebanyak 45\% dan tidak ada penurunan setelah imunisasi ke-2 maupun ke-3, bahkan cenderung meningkat. ${ }^{10}$

Penelitian ini menunjukkan imunisasi dasar DPT yang diberikan pada bayi sehat berumur 2, 3 dan 4 bulan memberikan respons imun yang baik dan memberikan faktor keamanan yang cukup tinggi sehingga masih layak digunakan pada program imunisasi nasional di Indonesia. Namun masih ada $20 \%$ kelompok yang rentan terhadap difteria, yang perlu menjadi perhatian, misalnya dengan cara pemberian imunisasi ulang pada umur 18-24 bulan yang bertujuan di samping meningkatkan kekebalan juga akan mengurangi kelompok yang rentan ini, atau dengan cara melakukan evaluasi terhadap jadwal imunisasi.

\section{Ucapan Terima kasih}

Ucapan terima kasih ditujukan kepada Direksi PT Bio Farma Bandung yang telah mendanai penelitian ini, dan kepada Kepala Bagian Ilmu Kesehatan Anak FKUP/ RSHS yang telah membentuk tim peneliti. Ucapan terima kasih juga disampaikan kepada Drs Hadyana MSc yang telah membantu dalam perhitungan statistik, serta kepada semua pihak yang telah membantu hingga penelitian ini dapat diselesaikan.

\section{Daftar Pustaka}

1. Schneerson R, Robbins JB, Taranger J, Lagergard T, Trollfors B. A toxoid vaccine for pertusis as well as diphteria? Lessons to be relearned. Lancet 1996: 346:1289-92.

2. Cherry JD. The epidemilogy of pertussis and pertussis immunization in the United Kingdom and the United States A comparative study. Curr Probl Pediatr 1984, 14:7-10

3. Bisgard KM, Hardy IRB, Popovic T. Respiratory diphteria in the United States, 1980-1995. Am J Public Health 1998; 88:787-91.

4. Departemen Kesehatan RI. Profil Kesehatan Indonesia tahun 1990.

5. Departemen Kesehatan RI. Profil Kesehatan Indonesia tahun 1995.

6. Ranuh IGN. Imunisasi upaya pencegahan primer.
Dalam: Ranuh IGN, Soejitno H, Hadinegoro SR, Kartasasmita C, penyunting. Buku Imunisasi di Indonesia. Jakarta. Pengurus Pusat Ikatan Dokter Anak Indonesia 2000. h. 1-3.

7. Vademekum Bio-Farma. PT Bio Farma, Bandung 1997. h. 48-51.

8. Efstratiou A, Maple PAC. Laboratory diagnosis of diphteria. Copenhagen, The Expanded Programme on Immunization in the European Region of WHO, 1994.

9. Prijanto M, Pangastuti R, Parwati D, Siburian F, Suprijanto E. Efektivitas imunisasi DPT pada bayi usia 2 bulan di Yogyakarta. Bul Pen Kes 1991; 19:38-50.

10. Bernbaum JC, Daft A, Anolik R, Samuelson J, Barkin $\mathrm{R}$, Duglas S, Polin R. Response of preterm infants to diphteria-tetanus-pertussis immunizations. J Pediatr 1985; 107:184-8.

11. Watemberg N, Dagan R, Arbelli Y, Belmaker I, Morag A, Hessel L, Fritzell B, dkk. Safety and immunogenicity of Haemophilus type b-tetanus protein conjugate vaccine, mixed int the same syringe with diphteria-tetanuspertusis vaccine in young infants. Pediatr Infect Dis J 1991; 10:758-61.

12. Bjorkholm B, Olling S, Larsson P, Hagberg L. An outbreak of diphteria among Swedish alcoholics. Infection 1987; 15:354-8.

13. Setiawan IM. Kadar antibodi bayi yang mendapat imunisasi DPT di RSCM, Puskesmas dan Posyandu. Jakarta: Tesis, Program Studi Ilmu Kesehatan Anak, FKUI, 1992.

14. Halsey N, Galazka A. The efficacy of DPT and oral poliomyelitis immunization schedules inititated from birth to 12 weeks of age. Bull WHO 1985; 63:1151-69.

15. Anderson EL, Belshe RB, Bartram J. Differences in reactogeniticity and antigenicity od acelluler and standard pertussis vaccines combined with diphteria and tetanus in infants. J Infect Dis J 1988; 157:731-7.

16. Barkin RM, Pichichero ME. Diphteria-pertusis-tetanus vaccine: Reactogenicity of commercial products. Pediatrics 1979; 63:256-9.

17. Galazka MA. Tetanus. Dalam: Galazka MA, penyunting. The immuological basis for immunization series. Global Programme for Vaccines and Immunization Expanded Program on Immmunization. World Health Organization, Geneva 1993.

18. Mortimer EA, Wharton M. Diphteria Toxoid. Dalam: Plotkin SA, Orenstein WA, penyunting. Vaccines, edisi ke-3. Philadelphia: WB Saunders 1999. h. 140-57.

19. Cody CL, Baraff LJ, Chery JD. Nature and rates of adverse reactions associated with DTP and DT immunization in infant and children. Pediatrics 1981; 68:65060.

20. Nolan T, Hogg G, Darcy MA, Varigos J, McEwen J. Primary course immunogenicity and reactogenicity of a new DTP (diphteria-tetanus-whole cell pertussis) vaccine. Pediatr and Child Health 1997; 33:413-7. 